\title{
SOCIO-PHILOSOPHICAL ANALYSIS OF LABOUR TRADITIONS: ETHNOCULTURAL ASPECT OF THE STUDY
}

\author{
(C) Vadim N. Goncharov, Larisa A. Tronina, Elena A. Khokhlova
}

\author{
Krasnodar University of the Ministry of Internal Affairs of the Russian Federation; \\ Stavropol State Pedagogical Institute; North Caucasus Federal University; \\ Stavropol, Russian Federation \\ science-almanac@mail.ru
}

In the development of modern society, organizational and ideological educational activities are important. Successful realization of economic and social development is impossible without taking into account human factor, in particular skills and knowledge of people, their production experience. Therefore, cultural, economic and everyday traditions are now gaining real significance, especially in different regional conditions. The increasing interest in folk culture is determined not only by the needs of the spiritual sphere, but also by the practical conditionality and vitality of folk labor traditions. This creates the need to study cultural and historical experience of the people and their practical application. The range of problems related to labor traditions is very wide. Some of them are important for the whole country, while others have regional specifics. Domestic researchers consider labor traditions as a constantly operating element of folk culture, concentrating collective experience transmitted from generation to generation. Under the influence of socio-economic and economic changes, some of them become anachronism and die off, while others, transforming, retain their significance. Some of them are secondary forms generated by new production and living conditions, by both previous and new labor experience.

Key words: traditions, culture, ethnic processes, society, consciousness, education, values.

[В.Н. Гончаров, Л.А. Тронина, Е.А. Хохлова Социально-философский анализ трудовых традиций:
этнокультурный аспект исследования] воспитательная деятельность. Успешная реализация экономического и социального развития невозможно без учета человеческого фактора, в частности навыков и знаний людей, их производственного опыта. Поэтому культурно-хозяйственные и бытовые традиции в настоящее время обретают реальную значимость, особенно в разных региональных условиях. Все более возрастающий интерес к народной культуре определяется не только потребностями сферы духовной, но и практической обусловленностью и жизненностью народных трудовых традиций. Тем самым создается необходимость изучения культурно-исторического опыта народа и его практического применения. Круг проблем, связанных с трудовыми традициями, очень широк. Одни из них имеют значение для всей страны, другие же обладают региональной спецификой. Отечественные исследователи рассматривают трудовые традиции как постоянно действующий элемент народной культуры, концентрирующий коллективный опыт, передаваемый от поколения к поколению. Под влиянием социально-экономических и хозяйственных изменений одни из них становятся анахронизмом и отмирают, другие же, трансформируясь, сохраняют свою значимость. Некоторые из них представляют собой вторичные формы, порожденные новыми производственными и бытовыми условиями, как прежним, так и новым трудовым опытом.

Ключевые слова: традиции, культура, этнические процессы, общество, сознание, воспитание, ценности.

Vadim N. Goncharov - Ph.D. (Advanced Doctorate) in Philosophy, Associate Professor, Krasnodar University of the Ministry of Internal Affairs of the Russian Federation, Stavropol, Russian Federation.

Larisa A. Tronina - Ph.D. (Advanced Doctorate) in Philosophy, Associate Professor, Stavropol State Pedagogical Institute, Stavropol, Russian Federation.

Elena A. Khokhlova - Ph.D. in Philosophy, Associate Professor, North Caucasus Federal University, Stavropol, Russian Federation.

Гончаров Вадим Николаевич - доктор фрилософоких наук, доцент, Краснодарский университет Министерства внутренних дел Российской Федерации, г. Ставрополь, Российская Федерация.

Тронина Лариса Анатольевна - доктор фрилософрских наук, доцент, Ставропольский государственный педагогический институт, е. Ставрополь, Российская Федерация. 
Хохлова Елена Анатольевна - кандидат фрилософрских наук, доцент, Северо-Кавказский федеральный университет, г. Ставрополь, Российская Федерация.

The problem of the present existence of modern labor traditions should be considered against the general background of the entire process of ethnocultural development of the people. The solution of this problem is possible only with a detailed study of the whole range of more private issues, taking into account the characteristics of life in certain regions.

Recently, a significant number of monographs and articles have been published on both general problems of the development of traditions and especially labor traditions of Russians living in various subjects of our State. Particular attention should be paid to the direction that determines the labor traditions associated with agrarian development, which allow solving the problems of modern agriculture. Without a doubt, this contributes to the study of the problems of agrarian history. The most important, in this context, special attention is paid to the advisability of taking into account economic traditions in the practice of modern economic activity in specific ethnic local conditions.

Labor traditions were also considered in the context of socio-cultural processes that determine the development of different regions. Here there is a problem of the importance of traditions in the historical perspective and the transfer of labor traditions in the process of ethnocultural ties that determine... "human quality and the resulting ability of social subjects to interact with the environment purposefully" [10, pp. 282-284], "complex interaction of various types of social communication" [2, pp. 5-10].

A long and diverse study by ethnographers, historians, philosophers of the most difficult problems of settlement and development of Russian regions, the development of the economic activity of the Russian population allows us to summarize the achieved results and determine the specific features of folk labor traditions in a specific region. At present, the problem of the connection between the traditions brought by immigrants with the process of settling and the livelihood of new settlers, the practice of transferring them, adapting and transforming them in new places is becoming extremely urgent.

Numerous ethnographic studies carried out recently indicate that over the course of the 16th-20th centuries immigrants in the Russian State were characterized by the preservation, first of all, of common traditions inherent in the Russian people, manifested in economic activity, families, customs and rites, in material and spiritual culture [7], noting "the influence of Orthodoxy on the formation and design of Russian culture." This contributed to the ethnic consolidation of the Russian people, settled in the vast territories of the State in the European part and in the Trans-Urals [11].

The disclosure of the practice of transferring traditions in the historical aspect, first of all, forces us to turn to the processes manifested during migrations. The directions and features of migrations of Russian immigrants were studied by various scientists throughout almost the entire twentieth century. Resettlements were assessed as a permanent factor that in the past determined, among other reasons, the agricultural development of the country. Researchers took a differentiated approach to the orientation of popular movements, highlighting the stages of settlement of various territories, movements within them and eviction to the neighboring areas. Thus, the undulating nature of migrations was determined. Economic development of the Russian regions took place gradually. As a result, the new settlers brought not only their traditional cultural skills and ideas, but also the experience gained during the intermediate stages of the resettlement movement. This suggests that the process of labor force generation in the new region is more intensive if it involves migrants from ecologically similar areas, which bring corresponding traditions of production activities.

The problem of creating a permanent population in a new region is also associated with the problem of attracting labor resources. So, for example, during the four centuries of migra- 
tions in the east of the country, beyond the Ural Mountains, a large permanent Russian population was formed, called Siberians since ancient times. This name has become a kind of ethnonym. The very penetration into the meaning of this concept already allows us to judge the role of folk traditions and their features in Siberia. The concept of a Siberian accumulates an idea of a person who is aware of his hereditary belonging to a certain territory, a hereditary connection with the development and management of this territory, who knows the wealth and complexity of the natural environment, who knows how to farm in its difficult conditions, who finally understands his ethnicity to the Russians and at the same time the peculiarity of his situation.

It is known that modern ethnic processes lead to the leveling of ethnic and cultural differences and to the widespread dissemination of elements of all-Russian culture. However, even with a sharply increased inter-ethnic interaction, nevertheless, due to the special specifics of local conditions, the originality of the spiritual appearance of the Siberian, and his economic and everyday traditions, remain. In the process of forming a permanent population of the region, only with sharing these traditions, the new settlers become Siberians, people who have adopted the previously accumulated very specific local experience.

When settling the Russians in various natural zones of Siberia, they entered into contacts with the local population, which had already established types of economic activity. With the advent of the permanent Russian population, which brought with it an agricultural culture, local territorial multisectoral complexes were created that covered a multi-ethnic population, but had a general economic orientation. Various branches of agriculture in these complexes were economically closely interconnected. The interrelation resulting from economic needs was further maintained and developed. Significantly, in the process of work, inter-ethnic contacts also strengthened personal relations, which were established not only in the field of production, but also penetrated into the domestic sphere.

In the industrial life of the Russian population, hunting and fishing techniques, clothing, summer and winter means of transportation, methods of procuring and storing provisions, some types of industrial and residential buildings of the indigenous population, especially adapted to local natural conditions, are preserved. These traditions reflect the synthesis of cultural and industrial inter-ethnic ties. At the same time, it happens that from the Russian population they again return to the indigenous inhabitants, who for some reason previously lost them.

Studying the labor traditions of the Russian Siberians, it is first of all necessary to bear in mind that the immigrants brought arable agriculture to Siberia, which since the 17th century has become the main industry of the economy there. To date, scientists have traced in detail how Russian farmers, moving from the Russian North, adapted their experience of land use and agricultural equipment to the conditions of Siberia. As the agricultural Russian economy expanded, cultural traditions, both all-Russian and newly developed, spread over a wide area. However, local features in traditions continued to maintain purely local significance. They are to a certain extent retained to date and require detailed study. It is well known how different in the past were the types of arable land tools among Siberian peasants, that is, technical equipment in the areas of the three-field system and in the areas of long unused agriculture. So, there are up to thirty types of plough design adapted to specific economic conditions. It was also established that in different rural areas there were various methods of cultivating fields depending on the quality of the soil.

In the conditions of modern machine technology, the principle of attitude to the land requires a historically reasonable approach, taking into account the gained experience. This applies particularly to the traditions that promote soil fertility. Studies of recent decades provide a lot of materials for this. For example, a certain geographical pattern is drawn to reduce the number of steam treatments from the south, from the steppes to the forest-steppe strip of 
Siberia. Local customs differ in the use and preservation of hayfields, in the clearing of new lands and their cultural status. There are examples of the modern use of local experience. The combination of folk traditions of land cultivation with the capabilities of modern technology allows us to develop techniques for noninversing plowing, which is used with great efficiency in some areas of Siberia.

The maintenance of labor traditions is directly related to the phenomena of public order, covering all residents of rural settlements. This refers to the traditions of collective implement of one-time works, decisions on which were made at general rural gatherings. These traditions were widespread among Russians everywhere. Let us pay attention to the fact that collective work was carried out without counting on material incentives. Collectivism contributed to the introduction of the spirit of competition, the development of optimal methods of labor, their consolidation and transfer to the younger generation. Such collective agricultural work of peasants was of great importance in maintaining and strengthening labor skills.

Some positive popular labor traditions were organically redefined after the establishment of Soviet power. On a new social basis, the traditions of socialist society began to develop and become embodied in everyday life. Thus, the experience of collective gratuitous labor was manifested in a new form at the communist subbotniks (voluntary unpaid work on days off). At the subbotniks, which over time acquired a state scale and from episodic became regular, the tradition of responsible attitude to work, concern for the well-being and well-being of the whole country is entrenched in the tradition, in the consciousness.

In the early years of Soviet power, evenings of collective rest of women were organized, to which they came with their needlework. The very form of such collective rest and work was taken from the traditions of rural life. In the future, clubs of craftsmen, lovers of needlework and craft, who unite at their place of residence in accordance with their interests, began to operate in cities and villages. These clubs contribute to the development of folk art, the transfer to the younger generation of ancient traditions of folk craftsmanship, which somehow determine the socio-cultural development of society [6, pp. 123-128], contributing to... "the processes of fundamental change... a cultural and civilizational picture of the world" [13, pp. 5-7], the spiritual sphere of the social system [8, pp. 6-12].

In the labor education of the peasantry, the most significant was the transfer of experience from the elders to the younger in the process of joint labor. This is how children were taught peasant labor in the family, as well as craftsmen taught their students. Currently, the transfer of labor traditions has been reflected in the practice of school labor education. So, in rural areas, high school students take part in work on farms and fields under the guidance of experienced specialists.

The mass movement of workers for the deployment of socialist competition, which has become an organic feature of the Soviet way of life, has acquired important national economic and ideological and educational significance. This movement develops one of the most significant folk traditions of collectivism. Based on respect for skills, the ability to organize work rationally, take initiative and sagacity, it calls for labor competition, taking place in an environment of community and mutual help.

A significant role is preserved by the traditions of labor holidays and rites woven into the annual rhythm of work. The functions of labor holidays are very diverse. Their essence lies in creating an emotional effect that activates psychological readiness for work and contributes to the most effective performance of work. In the festive atmosphere, the merits of the labor traditions of the collective, everyday work and its significance for society are better understood.

Modern labor holidays are traditionally timed to industrial cycles. They mark the beginning and the end of work, the most responsible moments of the production process, outstanding successes. The current holidays of the annual cycle have developed on the basis of 
traditional calendar holidays ("Conducts of Russian Winter," "Feast of Russian Birch"). They reflect the transfer of the labor relay from one time of year to another, the exaltation of conscientious work for the benefit of society.

In the new labor rite, the important place is occupied by professional agrarian holidays of all-Russian importance (Agricultural Workers Day, Machine Operators Day) and local ones (dedication to bakers or livestock breeders, holidays of labor dynasties, honoring best workers and veterans, which also reflect the popular custom of collective approval of conscientious labor. The feature of local labor holidays is their close intertwining with personal-family. Here, as though, traditions are united in two main areas of human life: industrial and family.

Thus, the statement of problem of labor traditions as a part of ethnic history and the history of culture inevitably leads to the need to study age-old economic experience in all its diversity, to analyze the reasons for the preservation of old traditions and the creation of conditions for the development of new ones. The study of traditions in the historical aspect allows not only to find the connection of times in the existence of certain phenomena, but also to draw conclusions necessary for modern life. Thus, the historical experience of the livelihood of immigrants in Siberia can be used in creating the most effective conditions for modern migrants and extended to other regions. Thus, historical and ethnographic, and sociophilosophical observations of a regional nature acquire general significance. On the other hand, the phenomena characteristic of the country as a whole, under the influence of local conditions, gain originality, without losing, in principle, their general essence, determine the national character. The national character can be found by examining the national education system [3, pp. 28-34]. It is necessary to organize upbringing and education systems based on scientific study of forms, methods, directions and mechanisms of personal development [9, pp. 15-18]. Dialogue and interaction of cultures provide... " promoting positive attitudes towards cultural differences" [4, pp. 7-10].

The use of past experience makes modern practice immeasurably easier. This is the main significance of socio-philosophical and historical-ethnographic studies that contribute to the implementation of historical continuity [14]. Historical continuity as the highest value is closely related to historical memory [16, pp. 41-47]. This ensures the proper level and quality of the obtained cultural product, which promotes inter-ethnic communication and dialogue of cultures [12], which determines modern sociality [1, pp. 168-177].

Attentive attitude to traditional cultural values contributes to the practical solution of problems to increase the effectiveness of production activities, and hence the level of material and spiritual cultural life of the Russian people at the modern stage of social development. "Culture is considered as the inner essence of human ideas..." [15, pp. 3-9]. "Culture is an essential characteristic of the social sphere of society, it is inseparable from the social activity of a person" [5, pp. 74-78].

\section{Лumepamypa}

1. Бакланова О.А., Бакланов И.С. Современная российская социальность в контексте социального конструкционизма // Вопросы социальной теории. 2015. Т. 7. № 1-2. С. 168-177.

2. Бакланова О.А., Бакланов И.С. Контуры типологического исследования социальности современного общества // Известия Саратовского университета. Серия: Философияя. Психология. Педагогика. 2014. Т. 14. № 2-1. С. 5-10.

3. Говердовская Е.В. Социокультурные и этнологические особенности региона основа модернизации высшего образования на Северном Кавказе // Ученые записки университета им. П.Ф. Лесгафта. 2007. № 7. С. 28-34. 
4. Говердовская Е.В. Особенности проектирования образовательного пространства высшей школы в поликультурном регионе // Экономические и гуманитарные исследования регионов. 2014. №4. С. 7-10.

5. Ерохин А.М. Социально-фрилософские аспекты развития культурной сферы общества // Экономические и гуманитарные исследования регионов. 2016. № 1. С. 74-78.

6. Ерохин А. М. Научно-информационный аспект исследования социокультурного развития общества в области культуры и искусства // Экономические и гуманитарные исследования регионов. 2015. № 2. С. 123-128.

7. Ивушкина Е.Б., Дашкова Е.В. Коммуникационный подход в музееведении. Новочеркасск, 2005.

8. Колосова О.Ю. Духовная сфера: универсализм и самобытность // European Social Science Journal. 2012. №11-2(27). C. 6-12.

9. Лобейко Ю.А. Социально-педагогический аспект активности личности в системе общественного развития // Экономические и гуманитарные исследования регионов. 2015. №1. С. 15-18.

10.Лобейко Ю.А. Социальная активность личности в обществе: социальнопедагогические аспекты формирования // European Social Science Journal. 2014. №7-2(46). С. 282-284.

11. Матяш Т.П., Матяш Д.В., Несмеянов Е.Е. "Науки о природе" и "науки о духе": судьба старой дилеммы // Гуманитарные и социально-экономические науки. 2015. № 1 (80). С. 10-16.

12. Мустафраев М.Б., Мустафраева 3.С., Мустафраев Ф.М. Национальное и национально-специфическое в системе межнационального общения // Гуманитарные и социально-экономические науки. 2016. № 1 (86). С. 83-89.

13. Несмеянов E.E., Колосова О.Ю. Информационная культура в контексте глобальных процессов // Гуманитарные и социально-экономические науки. 2014. № 3. C. 5-7.

14. Akaev V. Ethnocultural diversity and consolidation of Caucasus people unity: theoretic-methodologic analysis // Научный альманах стран Причерноморья. 2016. № 3 (7). C. 21-25.

15. Berkovskiy V., Tronina L. Social and historical aspect of interaction of ethnic culture and personality in the context of public development // Научный альманах стран Причерноморья. 2019. №1(17). С. 3-9.

16. Kuleshin M., Leonova N., Nemashkalov P. Historical consciousness as a part of national consciousness: to the problem statement of the research // Научный альманах стран Причерноморья. 2019. №1(17). С. 41-47.

\section{References}

1. Baklanova O.A., Baklanov I.S. Sovremennaia rossiiskaia sotsialnost v kontekste sotsial'nogo konstruktsionizma. Voprosy sotsialnoi teorii. [Modern Russian sociality in the context of social constructionism. Questions of social theory]. 2015. V. 7. No. 1-2. pp. 168-177 (in Russian).

2. Baklanova O.A., Baklanov I.S. Kontury tipologicheskogo issledovaniia sotsialnosti sovremennogo obshchestva. Izvestiia Saratovskogo universiteta. Seriia: Filosofiia. Psikhologiia. Pedagogika. [Contours of typological research of sociality of modern society. Izvestia, Saratov University. Series: Philosophy. Psychology. Pedagogics]. 2014. V. 14. No. 2-1. pp. 5-10 (in Russian). 
3. Goverdovskaya E.V. Sotsiokulturnye i etnologicheskie osobennosti regiona - osnova modernizatsii vysshego obrazovaniia na Severnom Kavkaze. Uchenye zapiski universiteta im. P.F. Lesgafta. [Sociocultural and ethnological features of the region are the basis for the modernization of higher education in the North Caucasus. Scientific notes of Lesgaft National State University]. 2007. No 7. pp. 28-34 (in Russian).

4. Goverdovskaya E.V. Osobennosti proektirovaniia obrazovatelnogo prostranstva vysshei shkoly v polikulturnom regione. Ekonomicheskie i gumanitarnye issledovaniia regionov. [Features of the design of the educational space of higher education in the multicultural region. Economic and humanitarian researches of regions]. 2014. No. 4. pp. 7-10 (in Russian).

5. Erokhin A.M. Sotsialno-filosofskie aspekty razvitiia kulturnoi sfery obshchestva. Ekonomicheskie i gumanitarnye issledovaniia regionov. [Socio-philosophical aspects of the development of the cultural sphere of society. Economic and humanitarian researches of regions]. 2016. No. 1. pp. 74-78 (in Russian).

6. Erokhin A.M. Nauchno-informatsionnyi aspekt issledovaniia sotsiokulturnogo razvitia obshchestva v oblasti kultury i iskusstva. Ekonomicheskie i gumanitarnye issledovaniia regionov. [Scientific and informational aspect of research of sociocultural development of society in the field of culture and art. Economic and humanitarian researches of regions]. 2015. No. 2. pp. 123-128 (in Russian).

7. Ivushkina E.B., Dashkova E.V. Kommunikatsionnyi podkhod v muzeevedenii. [Communication approach in museum studies]. Novocherkassk, 2005 (in Russian).

8. Kolosova O.Yu. Dukhovnaia sfera: universalizm i samobytnost. [Spiritual sphere: universalism and identity]. European Social Science Journal. 2012. No. 11-2(27). pp. 612 (in Russian).

9. Lobeyko Yu.A. Sotsialno-pedagogicheskii aspekt aktivnosti lichnosti v sisteme obshchestvennogo razvitiia. Ekonomicheskie i gumanitarnye issledovaniia regionov. [Socio-pedagogical aspect of individual activity in the system of social development. Economic and humanitarian researches of regions]. 2015. No. 1. pp. 15-18 (in Russian).

10. Lobeyko Yu.A. Sotsialnaia aktivnost lichnosti $v$ obshchestve: sotsialnopedagogicheskie aspekty formirovaniia. [Social activity of the individual in society: socio-pedagogical aspects of formation]. European Social Science Journal. 2014. No. 72(46). pp. 282-284 (in Russian).

11. Matyash T.P., Matyash D.V., Nesmeyanov E.E. "Nauki o prirode" i "nauki o dukhe": sudba staroi dilemmy. Gumanitarnye i sotsialno-ekonomicheskie nauki. ["Science of Nature" and "Science of Spirit": the fate of the old dilemma. Humanitarian and socioeconomic sciences]. 2015. No. 1 (80). pp. 10-16 (in Russian).

12. Mustafayev M.B., Mustafaeva Z.S., Mustafayev F.M. Natsionalnoe i natsionalnospetsificheskoe v sisteme mezhnatsionalnogo obshcheniia. Gumanitarnye i sotsialnoekonomicheskie nauki. [National and national-specific in the system of interethnic communication]. Humanitarian and socio-economic sciences. 2016. No. 1 (86). pp. 83-89 (in Russian).

13. Nesmeyanov E.E., Kolosova O.Yu. Informatsionnaia kultura v kontekste globalnykh protsessov. Gumanitarnye i sotsialno-ekonomicheskie nauki. [Information culture in the context of global processes. Humanitarian and socio-economic sciences]. 2014. No. 3. pp. 5-7 (in Russian).

14. Akaev V. Ethnocultural diversity and consolidation of Caucasus people unity: theoretic-methodologic analysis. Science almanac of Black Sea region countries. 2016. No. 3 (7). pp. 21-25. 
15. Berkovskiy V., Tronina L. Social and historical aspect of interaction of ethnic culture and personality in the context of public development. Science almanac of Black Sea region countries. 2019. No. 1(17). pp. 3-9.

16. Kuleshin M., Leonova N., Nemashkalov P. Historical consciousness as a part of national consciousness: to the problem statement of the research. Science almanac of Black Sea region countries. 2019. No. 1(17). pp. 41-47. 